\title{
Beyond a sacrificial spirituality: Enhancing flourishing pastoral ministers
}

\begin{tabular}{|c|c|}
\hline $\begin{array}{l}\text { Author: } \\
\text { Annemie Dille }\end{array}$ & \\
\hline $\begin{array}{l}\text { Affiliation: } \\
{ }^{1} \text { Faculty of The } \\
\text { Religious Stud } \\
\text { University, Bel }\end{array}$ & $\begin{array}{l}\text { ology and } \\
\text { es, Belgium } \\
\text { jium }\end{array}$ \\
\hline $\begin{array}{l}{ }^{2} \text { Department } \\
\text { Theology, Facl } \\
\text { Theology, Uni } \\
\text { Pretoria, Sout }\end{array}$ & $\begin{array}{l}f \text { Practical } \\
\text { Ity of } \\
\text { ersity of } \\
\text { Africa }\end{array}$ \\
\hline $\begin{array}{l}\text { Research Proj } \\
\text { Project Leade } \\
\text { Project Numb }\end{array}$ & $\begin{array}{l}\text { ct Registration: } \\
\text { : Y. Dreyer (D) } \\
\text { er: } 2546930\end{array}$ \\
\hline $\begin{array}{l}\text { Description: } \\
\text { Prof. Dr Anner } \\
\text { participating i } \\
\text { project, 'Gend } \\
\text { Practical Theo } \\
\text { Formation', di } \\
\text { Dr Yolanda Dr } \\
\text { Department o } \\
\text { Theology, Facl } \\
\text { Theology, Uni } \\
\text { Pretoria. }\end{array}$ & $\begin{array}{l}\text { ie Dillen is } \\
\text { the research } \\
\text { er Studies and } \\
\text { ogy Theory } \\
\text { ected by Prof. } \\
\text { yer, } \\
\text { Practical } \\
\text { lty of } \\
\text { ersity of }\end{array}$ \\
\hline $\begin{array}{l}\text { Correspondin } \\
\text { Annemie Dille } \\
\text { annemie.dille }\end{array}$ & $\begin{array}{l}\text { author: } \\
\text { @kuleuven.be }\end{array}$ \\
\hline $\begin{array}{l}\text { Dates: } \\
\text { Received: } 08 \mathrm{~J} \\
\text { Accepted: } 27 \\
\text { Published: } 25\end{array}$ & $\begin{array}{l}\text { une } 2017 \\
\text { une } 2017 \\
\text { Aug. } 2017\end{array}$ \\
\hline $\begin{array}{l}\text { How to cite th } \\
\text { Dillen, A., } 201 \\
\text { sacrificial spiri } \\
\text { Enhancing flo } \\
\text { pastoral minis } \\
\text { Teologiese Stu } \\
\text { Theological St } \\
\text { a4694. https:/ } \\
\text { 10.4102/hts.v }\end{array}$ & $\begin{array}{l}\text { is article: } \\
\text {, 'Beyond a } \\
\text { uality: } \\
\text { rishing } \\
\text { ers', HTS } \\
\text { dies/ } \\
\text { Idies 73(4), } \\
\text { 'doi.org/ } \\
\text { 3i4.4694 }\end{array}$ \\
\hline $\begin{array}{l}\text { Copyright: } \\
\text { (C) 2017. The A } \\
\text { Licensee: AOS } \\
\text { is licensed unc } \\
\text { Creative Comr } \\
\text { Attribution Lic }\end{array}$ & $\begin{array}{l}\text { uthors. } \\
\text { S. This work } \\
\text { er the } \\
\text { lons } \\
\text { ense. }\end{array}$ \\
\hline Read online: & \\
\hline 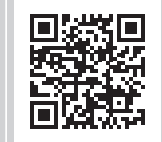 & $\begin{array}{l}\text { Scan this QR } \\
\text { code with your } \\
\text { smart phone or } \\
\text { mobile device } \\
\text { to read online. }\end{array}$ \\
\hline
\end{tabular}

This contribution explains the value of self-giving and critically questions the discourse on self-sacrifice in relation to ministerial spirituality. In practice, what others may describe as selfsacrifice may be experienced by a care-giver as an adequate form of self-giving inspired by the Christian vocation, without any praise for one's own deeds, without any overestimation of the heroic character of one's own giving. An inherent danger in the concept of self-sacrifice is a closedness to critically assessing the balance of power in one's own relationships. In this sense, theologians are asked to use the concept self-sacrifice with caution, as the theological language may inspire people, ideas and the general discourse further than intended.

\section{Introduction}

A full page in one of the major newspapers in Flanders, Belgium, was devoted to the time pressure of a young priest. How does his week look like, if there is such a shortage of priests, as the newspapers were reporting the day before? The priest is quoted:

A work day usually starts at 8 am, and ends at $11 \mathrm{pm}(. .$.$) . My calendar is rather full, but there is always$ place for unforeseen phonecalls or private talks. As a priest, you are always available for the community. There is space for everyone. Sometimes, it is searching how to organize all these things. (De Decker 2017)

If one looks at the week-schedule, published on the same page of the newspaper, one can discover that this priest is actually also taking time for more personal activities, such as working on his master's thesis for the university, and making time for his family. What is at stake here is his expression that a priest is 'always available for the community': an expectation that is equally shared by many parishioners.

Many priests and pastoral ministers have the idea that parishioners or other people for whom they have pastoral responsibility expect them to be available $24 \mathrm{~h}$ a day. We see in fact that some pastoral ministers are prepared to engage extensively in care for others, to such an extent that their personal life often seems to get sidelined. Many pastors are able to find a balance between caring others and caring for oneself. Many others feel pressed to sacrifice themselves, as influenced by ecclesiological and theological ideas.

Must pastors care for others in such a radical way that they even risk their own lives and that they leave everything behind in order to care for others? I will show an adequate form of self-giving in pastoral work and demonstrate how we can avoid a sacrificial model of pastoral care.

The main thesis in this contribution is that a sacrificial discourse on pastoral care should be avoided as much as possible. In some cases, sacrifice is valuable, but there are dangers inherent in the sacrificial discourse. The main element for this critique is that a sacrificial discourse may be a disguise for power, its abuse and legitimatising the imbalance of power (Gärtner 2009). As such, power and the balance of power are always at play in pastoral care. A pastoral care relationship can never be totally symmetric, and the asymmetry implies unequal power. Nevertheless, it is very important for all people offering pastoral care to be aware of their own power and the balance of power in their relationships, in order to avoid power abuse.

A second reason for critiquing the sacrificial discourse concerns the pastoral minister's own place. This reason is clearly linked with the (ab)use of power as well. One often thinks that sacrifice is giving up the importance of one's own person, placing the other first at the expense of self, out of a generous mindset. But in fact, one often sees that by the discourse on sacrifice or the sacrificial acts themselves, one strives for recognition, self-validation and implicitly places the self at the centre. The pastor is sometimes not open to the real needs of the other because one's own giving

Note: This article is an adapted version of an article, published earlier by Annemie Dillen (2011a). 
is considered so important. This can be considered a form of power over the other and putting the 'ego' at the centre while legitimising the action as other-centric. At the same time some people who seem to 'sacrifice' themselves for others may easily suffer from a burn-out because of a lack of selfcare (see Bisschops 2006; Pieper 2006; Smeets 2006). I will distinguish some elements that are important in order to come to an adequate self-giving, valuable for both the other and for the self.

\section{Images of pastoral care}

In pastoral theological literature, we find a critical reflection on 'sacrifice' mainly by feminist pastoral theologians. On the one hand, the image of the pastor as 'shepherd' is criticised while on the other hand (Bons-Storm 1996), the image of the Good Samaritan is proposed in order to stimulate a lifegiving balance between care for the other and care for the self or a fruitful understanding of self-gift (Stevenson-Moesner 2005). I will explain both metaphors, while being aware that both have their advantages and their shortcomings.

\section{Shepherd}

Pastors are often presented as shepherds, as classically imagined by the story of the good shepherd who is doing everything in order to save his sheep or the shepherd as a metaphor for Jesus Christ, the Good Shepherd (with capitals), who even gave his life for his sheep.

One of the protagonists of the theological reflection on ministry is the American Protestant pastoral theologian Seward Hiltner (2005). He used (in 1959) the image of the 'solicitous shepherd' to help pastors and chaplains to reflect on their own identity, in reference to Luke 15. In this view, to be a shepherd means to heal, to sustain, to guide and to reconcile, which can be seen as the classical four tasks of pastoral care (Clebsch \& Jaekle 1964).

The image of the good shepherd in the New Testament (Lk 15) refers to the care for the lost sheep. One critique is that the sheep may be sought because it should stay with the flock (Bons-Storm 1996). The analogy may reflect the idea that people have to adapt to the group. One can ask whether the shepherd metaphor allows enough space for real diversity between people and for looking at the real needs of individual people. One could ask, following the analogy, why the sheep got lost in the first place. Maybe the 'sheep' is not really accepted within the group or is ill. There may be structural, social and personal reasons for the sheep to get lost. It is important that these reasons are dealt with as well. In this way, the image of the 'prophet' may fit better (see Dillen, Liègeois \& Vandenhoeck 2009a; Dillen \& Vandenhoeck 2011).

Alternatively, if we continue to use the shepherd image, we may refer explicitly to Ezra 34. In the Old Testament, the shepherd is presented as courageous, as someone who strives for justice (Ezr 34:16). The Scottish theologian Alastair Campbell used (in 1981) the metaphor of the courageous shepherd as a critique to and a continuation of the ideas of Hiltner (Campbell 2005). Campbell wanted to stress that ministry is more than listening, inspired by therapeutic especially client-centred - skills. It is not a soft job, with connotations of 'rural' and 'parochial', but it requires much courage, the courage to protest against violence and injustice and to be responsible for the most vulnerable. The shepherds in the Old Testament had a good reputation. The metaphorical use of the shepherd in the Old Testament referred to tenderness, healing skills and self-sacrifice.

Although this image of the courageous shepherd helps many pastoral ministers to think about their own identity and stimulates them to really care for the other, there are also some limits to this image. The primary critique of this image is the sacrificial connotation and the dangers this may have when the biblical metaphor functions in concrete situations.

The image of the courageous shepherd may reflect how the shepherd risks his own life in order to care for the lost sheep, but it can also be interpreted as someone more knowledgeable about what is best for the sheep. It is the person of the shepherd that is central in the metaphor, not so much the community of believers (the sheep) and their mutual care. The metaphor of the shepherd may go hand in hand with forms of clericalism, as an excessive focus on the ordained minister as different from the 'flock', or lay people. The 'flock', or the 'sheep' - the community of believers and other people - from this perspective may be considered passive, whereas the shepherd is the one who acts (Foucault 1992; 1994; Steinkamp 1999). One can ask how this metaphor stimulates the agency of each actor, lay persons included.

This metaphor may disguise the weaknesses and mistakes of the pastor. By focusing on the self-sacrifice and courage of the shepherd or 'pastor', one may get the impression that it is all about care for the other, but in the end the other is not always treated justly. If one loses oneself, how may one continue to care? Might this not place a heavy load on the shoulders of the other, who may start to worry about the pastor, thereby changing the roles? The idea of self-sacrifice may blind people to their own mistakes (see Gudorf 1996). Because nobody is perfect, pastors may also make mistakes and abuse their power, whether it is minor or major. The idea that one is sacrificing himself or herself may however disguise the problems within pastoral care because one may say: 'I am doing so much for this person'. The self-sacrificing pastoral caregiver may not notice certain issues, such as the recipient's dependency on the caregiver - that he or she does not learn to stand on his or her own feet - or that he or she receives unwanted forms of care (Gärtner 2009).

These critical reflections on the 'courageous shepherd' do not seek to critique the reference in Ezekiel 34. This is extremely valuable because in addition to referring to the person of a shepherd, they refer to the healing and tender care of God, who may be called (precautiously) the 'Good Shepherd'.

Nevertheless, it is important to search for complementary models, such as the model of the Good Samaritan. 


\section{Good Samaritan}

In the biblical metaphor of the good Samaritan one can find an alternative for the shepherd metaphor and an implicit critique of some interpretations of sacrifice, although it does not prevent all the dangers I just mentioned. The feminist pastoral theologian Jeanne Stevenson Moessner uses the image of the good Samaritan and explains how the Samaritan gives himself to the other, but without losing himself (Stevenson-Moesner 2005). He takes the wounded person to an inn, where he asks the innkeeper to care for the man and pays him to do so. He gives quite a lot of himself, but at the same time the care is shared with other 'professionals'. This can be considered as a reference to the necessity of cooperation with others, of integration of pastors or chaplains in care services and sharing caregiving. It can also be seen as a reference to the fact that pastoral care is not unlimited. A pastor or chaplain has to continue on his or her journey to other people and to home and family. A similar idea is found in the story of the disciples on their way to Emmaus after the death of Jesus, a story often used to demonstrate pastoral care.

Knowing that one is not alone in doing pastoral work is very significant for pastoral ministers. It may help them to avoid presenting themselves as ultimate saviours upon whom others are dependent. I may help to prevent other forms of misuse of pastoral power. Therefore, it is important to refer to other professionals when needed, for social, psychic or physical support, for juridical advice and so on. Pastoral work is aimed at caring for the whole person, with a focus on the spiritual elements, for which they are specifically trained. But overall, a great deal of their work can be quite general as they are often the first spokespersons for people who need help, but they may have to refer to others, rather than aiming to solve everything themselves or pretending to be the most crucial actor.

The metaphor of the good Samaritan may help us to reflect on the relevance of shared care. Nevertheless, the good Samaritan is not an ideal metaphor either - as with every image, it has it shortcomings. It does not stimulate our reflection on the other's giving. The victim is very passive in this story, just like the flock in the story of the good Shepherd is waiting to be found. It is important that pastors recognise the giving of the other because in being able to 'give' to others, to care for others, people may feel their full humanness, their agency, which is a form of 'power' to choose one's deeds and to give meaning to others. If there is an excessive focus on the pastor's self-sacrifice, this giving of the other may be neglected. I do not recommend that the roles must change, as it is the pastor who bears the responsibility for the relationship and who provides the most care. But allowing the other to give and to recognise the other for his or her giving is very valuable for the other, and also for the pastor (Dillen 2011b). It is a danger when the pastor gets all his or her love for the work from what he or she receives from the other or when he or she gives in order to receive something back (do-ut-des). But with this precaution about benefit in the other direction, it is nevertheless very important to stimulate pastors to be open to the giving of others: they are not the only ones who care and give.

Some pastors have much difficulty with receiving from others because they have learned to care for others, or have always taken the caring role, and receive self-validation through caring (Thans \& Lampe 2003). These pastors may be very sensitive to burn-out - at a certain moment they may give too much. They are also sensitive to the abuse of power through limitless care, as I showed before when mentioning how self-sacrifice may function as a disguise of mistakes or a stimulus to maintain the other's dependency. Both in literature and in the practice of pastoral supervision, pastors are stimulated to look at patterns in their families of origin and to critically rethink the balances of give and take in their own private lives so that they become more free to have a healthy balance of give and take in pastoral relationships.

\section{Models of pastoral care}

The discussion about metaphors of pastoral care has led us to a critical reflection on power and self-sacrifice. A similar reflection can be stimulated by looking at contemporary models of pastoral care. Ruard Ganzevoort and Visser (2007) distinguish, partly in line with Gerben Heitink (1996), four main models of pastoral care, and place them in a historical line, but also acknowledge that they are all present today. These models are the kerugmatic or sacramental model, the therapeutic model, the model of 'presence' and the hermeneutical-narrative model.

I will focus here on the kerugmatic or sacramental model on the one hand, and on the model of presence on the other hand, as they seem to contrast most. I will show that in terms of sacrifice and power, they have surprisingly much in common.

The kerugmatic-sacramental model focuses on the message, transmitted by a leader who refers to the tradition, who receives his or her power from a relation with the divine or from his or her ordination and its sacred status (Heitink 1996). The main theological approach that is present in this form of pastoral care can be considered deductive: from the tradition and the general theological and biblical ideas to their application in concrete situations. This kerugmaticsacramental model has been very popular in the beginning of the 20th century. It is still present today, for instance in pastoral ministers focusing on the sacraments and their healing power, more or less separated from interest in the relationship with people's life experiences, or in a major focus on clerical attitudes.

People acting on the basis of this kerugmatic-sacramental model often see themselves clearly as ministers acting out their vocation, bringing God's call into reality. They may do everything to spread the message, to give others the opportunity to receive the sacraments, and may consider themselves as only an instrument in the hands of God. This 
model focuses on the replaceability of pastoral ministers (by other ordained ministers), as it is not one's own personhood, but the tradition and the sacramental grace that is central. The legitimisation of one's own position in terms of divine power in combination with a sacrificial spirituality that may lead to a certain blindness to power abuse, as I have already explained.

The presence model, developed primarily by the Dutch author Andries Baart (2001), attempts avoiding the focus on the status of the minister, as he or she is chiefly someone who works between people, who is present on the street, in places where people live and dwell. The presence approach in pastoral care tries to be radically inductive, starting from people's lived experiences, and only introduces theological ideas if the people themselves speak about something religious. This model may also stimulate pastoral care-givers to sacrifice themselves, as it emphasises the importance of going to the other, of being available as much as possible, of caring for people without concern for efficiency or time. A pastoral minister may have difficulty in safeguarding the boundaries of his or her own engagement, which may be expand infinitely and the effort never be enough. Additionally, the boundaries between the minister and the people who receive pastoral care may become very unclear. The presence model tries to avoid the use and abuse of power as much as possible, by focusing on a friendship-like relationship between the care giver and the care receiver. Because a pastoral relationship however is never totally symmetrical, this friendship-like relationship may lead to forms of power abuse, such as sexual misconduct, betrayal of trust and so on.

What can a pastor do to avoid this power abuse or the negative consequences of sacrifice? The combination of elements of both models may lead to a balanced form of pastoral care, while becoming sacrificial only when really necessary. A Christian spirituality may help people to acknowledge that caring for another is not fully one person's task. It may prevent zealousness and action without inspiration. A Christian prayer life and a strong vocational spirituality may help people to consider their work permanently in the light of God's support and God's eschatological promise.

On the basis of the kerugmatic-sacramental model, a pastoral worker may have the idea that he or she is only a means in the hands of God but may fall into considering himself or herself as also wielding God's power, as his earthly representative. When this model goes together with a strong belief in pastoral care as striving for a form of power with people (Stortz 1993), for empowering others and sharing their life, the danger of power abuse and the legitimation of sacrificial spirituality may be diminished.

In practice, the models as I have sketched them are typologies, of course, and there are few pastoral workers who represent a model fully - thankfully, as these models each have their limitations.

\section{Constructive elements of self-giving in pastoral situations}

Through my critical reflection, I have made it clear that the discourse of self-sacrifice may be dangerous in some ways as it may lead to, or legitimise forms of power abuse. This does not mean that self-sacrifice is always bad or that there is no place for self-giving in pastoral care.

I use self-sacrifice here as giving oneself away to the other, where the I is threatened by the self-gift. I use it mostly in a negative way. At certain moments, however, it may be necessary to sacrifice oneself because the needs of the other are very high and urgent (Browning et al. 2000). In fact, the practice of self-sacrifice is to be distinguished from the ideas about the necessity of self-sacrifice, which I call a 'sacrificial mentality'.

What we need for pastoral care and pastoral theology is a mentality and a practice of self-giving, where sacrifice as a practice can have a place. In order to avoid the path to power abuse, it is important that the general idea of self-giving be characterised by at least four elements.

A first important element when speaking about self-giving and self-sacrifice in pastoral relations is the aim of the selfgiving. Suicide bombers may also feel the need to be valued for their self-sacrifice. A main criteria in our search for an adequate form of self-giving and self-sacrifice is the 'object' of the giving that must be ethically qualified. Of course, terrorists also think they aim to do good, but when I say 'ethically qualified' I mean qualified by the principles and values that are typical (not unique) for Christian ethics, with the option for the poor as one of the main values.

A second element is an openness to the self-giving of the other. This does not compensate for the self-giving of the pastor, and it clearly should not be inspired by a do ut des mentality. This openness to how the other - often called the pastoral care receiver - may give is important in light of new tendencies in pastoral theology where empowerment is a main aim (Miller-McLemore \& Gill-Austern 1999). Being able to give, both to one's own context and to the pastoral ministry, as well as to be recognised for this giving is very important for experiencing self-value, to avoid a unilateral focus on passivity and dependency. Therefore, I prefer not to use the words 'pastoral care giver' and 'pastoral care receiver' (Dillen, Liègeois \& Vandenhoeck 2009b). There is often much more - sometimes hidden - mutuality than we expect. Just as a relation between parents and children is not symmetrical, but there can be forms of mutual give and take, this is similarly the case for pastoral relations; the recognition of the basic asymmetry remains significant in avoiding unjust crossing of boundaries.

A third element is that a pastoral minister has to give himself or herself to others - the care for others is the essence of what the function and the Christian spirituality include. At the 
same time, a pastoral care-giver should try to be able to share aspects of care with others. It should be stimulated to work in teams, when possible with diversity. I think of care services with multidisciplinary teams of psychologists, nurses, medical doctors and so on, and about pastoral teams with more than one pastoral minister, and if possible, also a group of volunteers. Pastoral workers should be able to share about the work with colleagues, in forms of intervision and supervision - with respect for the privacy of the other. In parishes it is very important that priests do not work alone or feel themselves responsible for everything, even when practical and legal situations stimulate this idea. People working in parishes, as professionals or volunteers, should also share with others in the parish - also with people with other jobs, for instance in politics, in social care, in media, and with others crossing the boundaries of the parish. The metaphor of the shepherd, about which I asked critical questions, may be used in a positive way when it refers to the shepherding of all Christians, and not only to the leader.

Sharing care-giving with other people is very important to avoid the pitfalls of a self-sacrificial mentality. At the same time it is a part of self-care. Pastoral workers need to care for themselves as well, not only for others. They give from who they are, and they themselves receive from God, from others, from their self-care. The Christian tradition about self-love and neighbour love supports them in this self-care.

A fourth element on which I want to focus as part of an adequate understanding of self-giving pastoral care also has to do with self-care. It concerns the value of spirituality. Self-giving is best inspired by an intensive spiritual life. When one only gives to others, without 'food for the soul', without a personal prayer life, without the belief that one is not alone in the effort or that one must be perfect, the giving may become 'fanatic'. Of course, when I say that spirituality is important as inspiration, this does not mean that the concrete care and the spirituality are totally separated. One can even experience spirituality in caring - spirituality need not only be associated with separate spaces and times (during Eucharist, when praying), but may also be found within the practice of pastoral care (Dillen 2009).

A Christian spirituality (grounded in reality, stimulating cooperation and not considering suffering as valuable as such) that inspires pastoral care may help pastoral ministers to look at themselves in terms of being a 'good enough pastor', or a 'good enough caregiver' (for the concept 'good enough', see also Miller-McLemore 2003; Winnicott 1974). Someone may know that he or she is loved by God in his or her whole person, not just under the condition of infinite selfgiving, as in the form of self-sacrifice. Pastoral workers do not need to be perfect in terms of giving everything. Alastair Campbell referred to a similar idea when he wrote about the courageous shepherd (Campbell 2005). In the end, he says, it is only Jesus who is really the Good Shepherd and one must be cautious not to boast about embodying the image of the shepherd oneself - it always has to be put in connection with Jesus' perfect and enabling love that cannot be expected of human beings without God's help.
The knowledge that one can be 'good enough' and is loved by God may help to reflect critically about one's own limits and mistakes, and to stimulate pastoral workers to an adequate self-giving that avoids an ideology of self-sacrifice. Self-sacrifice is often reflected upon in terms of heroism (Pollefeyt 1999). The danger of heroism, however, is that it closes the subject's capacity for critical reflection on himself or herself. The idea of a 'good enough pastor' may avoid this focus on heroism and help pastoral ministers to see that they are people like everyone, with strengths and weaknesses. It may also be an antidote against what is called in literature, the messiah complex (Gärtner 2009), the idea of wanting to be and to do everything for everyone. Pastoral ministers have a vocation to develop their own strength and to seek ways to deal more constructively with their weaknesses. This does not mean, however, that they have to be perfect people.

\section{Conclusion}

I have focused on the value of self-giving and have critically questioned the discourse on self-sacrifice. In practice, it will be very difficult to distinguish self-giving from self-sacrifice. I used the word self-sacrifice with more negative connotations and the word self-giving as an adequate form of self-giving, which may be called self-sacrifice by others. However, I see another significant difference in these terms; when selfsacrifice becomes part of a discourse, an ideology, a normative system that judges others, it becomes dangerous. In this case, it is doubtful that the giver is open to self-criticism. Nevertheless, in practice, what others may describe as selfsacrifice may be experienced by a care-giver as an adequate form of self-giving inspired by the Christian vocation, without any praise for one's own deeds, without any overestimation of the heroic character of one's own giving. An inherent danger in the concept self-sacrifice is a closedness to critically assessing the balance of power in one's own relationships. In this sense, theologians should also use the concept selfsacrifice with caution, as the theological language may inspire people, ideas and the general discourse further than intended.

\section{Acknowledgements Competing interests}

The author declares that she has no financial or personal relationships which may have inappropriately influenced her in writing this article.

\section{References}

Baart, A., 2001, Een theorie van de presentie, Lemma, Utrecht.

Bisschops, A., 2006, 'De werkdruk van basispastores. Ondermijnende en constructieve strategieën', Praktische Theologie 1, 43-59.

Bons-Storm, R., 1996, Incredible woman. Listening to women's silences in Pastoral Care and counselling, Abingdon Press, Nashville, TN, pp. 27-30.

Browning, D.S., Miller-Mclemore, B.J., Couture, P.D., Brynolf Lyon, K. \& Franklin, R.M., 2000, From culture wars to common ground. Religion and the American family debate, Westminster John Knox Press, Louisville, KY.

Campbell, A., 2005, 'The Courageous Shepherd', in R.C. Dykstra (ed.), Images of Pastoral Care. Classical readings, pp. 54-61, Chalice, St. Louis, MO.

Clebsch, W.A. \& Jaekle, C.R., 1964, Pastoral care in historical perspective, PrenticeHall, Englewood Cliffs, NJ. 
De Decker, M., 2017, 'Interview met Herbert Vandersmissen (35), Priester van dertien parochies in Lokeren-Moerbeke', We moeten het vuur brandend houden, in De Standaard, 5th mei.

Dillen, A., 2011a, 'De zelfgave van pater Damiaan als inspiratie voor pastores? Over versluierde machtsaanspraken en een evenwichtige spiritualiteit', Collationes: Vlaams Tijdschrift voor Theologie en Pastoraal 41(2), 185-198.

Dillen, A., 2011b, 'Doing justice in primary relationships. Towards a just way of dealing with power dynamics in Pastoral dialogue based on the though of Ivan Boszormenyi-Nagy', in M. Riemslagh, A. Liégeois, J. Corveleyn \& R. Burggraeve (eds.), After You. Relational ethics in dialogical counselling, pp. 217-232, Peeters, Leuven.

Dillen, A., 2009, 'Caritas: "Machtig" kerkelijk heilshandelen. Aspecten van diaconaal handelen in het licht van machtsmechanismen', Collationes 373-388.

Dillen, A., Liègeois, A. \& Vandenhoeck, A. (ed.), 2009a, De moed om te spreken en te handelen. Profetisch pastoraat, Halewijn, Antwerpen, pp. 132-172.

Dillen, A., Liègeois, A. \& Vandenhoeck, A., 2009b, 'Pastores als spirituele zorgverleners. Identiteit, professionaliteit en uitdagingen', in A. Dillen, A. Liègeois \& A Vandenhoeck (eds.), De moed om te spreken en te handelen. Profetisch pastoraat pp. 212-232, 216-217, Halewijn, Antwerpen.

Dillen, A. \& Vandenhoeck, A. (ed.), 2011, Prophetic witness in world Christianities rethinking Pastoral care and counseling (International Practical Theology), Litverlag, Münster.

Foucault, M., 1992, 'Omnes et singulatim. Zu einer Kritik der politischen Vernunft', in J. Vogl (ed.), Gemeinschaften. Positionen zu einer Philosophie des Politischen, Suhrkamp Verlag, Frankfurt.

Foucault, M., 1994, Was ist Kritik?, Berlijn, Merve Verlag.

Ganzevoort, R. \& Visser, J., 2007, Zorg voor het verhaal. Achtergrond, methode en inhoud van pastorale begeleiding, Zoetermeer, Meinema.
Gärtner, S., 2009, Zeit, Macht und Sprache, Pastoraltheologische Studien zu Grunddimensionen der Seelsorge, Herder, Freiburg, pp. 162-173.

Gudorf, C.E., 1996, 'Sacrificial and parental spiritualities', in A. Carr \& M.S. Van Leeuwen (eds.), Religion, feminism and the family, pp. 291-309, Westminster John Knox Louisville, KY.

Heitink, G., 1996, Pastorale zorg. Theorie, differentiatie, praktijk, Kok, Kampen.

Hiltner, S., 2005, The Solicitous Shepherd, in R.C. Dykstra, images of Pastoral care, Classical Readings, Chalice, St. Louis, MO, pp. 47-52.

Miller-McLemore, B.J., 2003, Let the children come: Reimagining childhood from a Christian perspective (Families and Faith Series), Jossey-Bass, San Francisco, CA, p. $49 \& 145$

Miller-McLemore, B.J. \& Gill-Austern, B.L. (ed.), 1999, Feminist and womanist Pastoral theology, Abingdon Press, Nashville, TN.

Pieper, J., 2006, 'Burn-out in het rooms-katholieke basispastoraat. Stressoren en hulpbronnen', Praktische Theologie 1, 60-77.

Pollefeyt, D., 1999, 'Victims of evil or evil of victims?', in H.J. Cargas (ed.), Problems unique to the Holocaust, pp. 67-82, University Press of Kentucky, Lexington, KY.

Smeets, W., 2006, 'Pastores en burn-out: mogelijkheden en grenzen. Een terugblik', Praktische Theologie 1, 78-84.

Steinkamp, H., 1999, Die sanfte Macht der Hirten. Die Bedeutung Michel Foucaults für die praktische Theologie, Matthias-Grünewald-Verlag, Mainz.

Stevenson-Moesner, J., 2005, 'The self-differentiated Samaritan', in R.C. Dykstra (ed.), Images of Pastoral care. Classical readings, pp. 62-68, Chalice, St. Louis, MO.

Stortz, M.E., 1993, Pastor power, Abingdon Press, Nashville, TN.

Thans, M. \& Lampe, A., 2003, Balans tussen werk \& thuis, Meinema, Zoetermeer. Winnicott, D.W., 1974, Playing and reality, Penguin, Harmondsworth, p. 11. 